\title{
Reasons that led hypertensive elderly to seek assistance in primary care
}

\author{
Motivos que levaram idosos com hipertensão arterial a procurar atendimento na atenção \\ primária
}

\section{Razones que llevaran a los ancianos hipertensos a buscar atención en la atención primaria}

Roberta Fernanda Rogonni Ferrari ${ }^{1}$, Daysi Mara Murio Ribeiro ${ }^{2}$, Fabiana Cristina Vidigal ${ }^{2}$, Sonia Silva Marcon ${ }^{2}$, Vanessa Denardi Antoniassi Baldissera², Lígia Carreira²

We aimed at verifying the complaints causing elderly hypertensive patients search for a health center in a municipality of the state of Paraná-Brazil. Analytical and exploratory retrospective study conducted between November 2013 and January 2014, with 106 records of elderly hypertensive who underwent nursing consultation in the past five years. Elderly females $(73.5 \%)$, up to 70 years (61.3\%), with a partner (57.5\%) and up to 4 years of study $(73.5 \%)$ accounted for most of the sample. The main complaints causing elderly hypertensive patients to seek health care focused on endocrine and nutritional diseases (36\%). A significant association between sex and search the health service having hypertension as a major complaint, but no association was observed between complaints related to hypertension and number of interventions prescribed by nurses. The data revealed enable the planning of specific interventions to the needs of elderly hypertensive allowing adjustments in care.

Descriptors: Health of the Elderly; Hypertension; Health Services; Primary Health Care; Nursing.

Objetivou-se verificar as queixas que motivaram idosos hipertensos a procurar um centro de saúde em um município do Estado do Paraná, Brasil. Estudo analítico e exploratório de caráter retrospectivo realizado entre novembro de 2013 a janeiro de 2014 com 106 prontuários de idosos hipertensos que realizaram consulta de enfermagem nos últimos cinco anos. Idosos do sexo feminino (73,5\%), até 70 anos (61,3\%), com companheiro (57,5\%) e até 4 anos de estudo (73,5\%) representaram a maioria da amostra. As principais queixas que motivaram idosos hipertensos a buscar assistência à saúde concentraram-se nas doenças endócrinas e nutricionais (36\%). Houve associação significativa entre sexo e busca do serviço de saúde tendo a hipertensão arterial como principal queixa, mas não foi observada associação entre queixa relacionada à hipertensão arterial e número de intervenções prescritas pela enfermagem. Os dados revelados possibilitam o planejamento de intervenções específicas às necessidades dos idosos hipertensos permitindo, assim, adequações no cuidado.

Descritores: Saúde do Idoso; Hipertensão; Serviços de Saúde; Atenção Primária à Saúde; Enfermagem.

El objetivo fue verificar quejas que motivaron ancianos hipertensos a buscar un centro de salud en municipio del estado de Paraná-Brasil. Estudio analítico y exploratorio, de naturaliza retrospectiva, llevado a cabo entre noviembre 2013 y enero de 2014, con 106 registros médicos de ancianos que efectuaron consulta de enfermería en los últimos cinco años. Ancianos del sexo femenino $(73,5 \%)$, hasta 70 años $(61,3 \%)$, con compañero $(57,5 \%)$ y hasta 4 años de estudio $(73,5 \%)$ representaron la mayoría de la muestra. Las principales quejas de los ancianos que buscan atención centraron en enfermedades endócrinas y nutricionales (36\%). Hubo asociación significativa entre sexo y búsqueda por el servicio de salud, teniéndose la hipertensión como principal queja, pero no hubo asociación entre quejas relacionadas con la hipertensión y el número de intervenciones prescritas por la enfermería. Los datos permitieron planificación de intervenciones específicas para necesidades de ancianos hipertensos, posibilitando, así, adecuaciones en la atención.

Descriptores: Salud del Anciano; Hipertensión; Servicios de Salud; Atención Primaria de Salud; Enfermería.

\footnotetext{
${ }^{1}$ Universidade Paranaense. Umuarama, PR, Brazil.

${ }^{2}$ Universidade Estadual de Maringá. Maringá, PR, Brazil.

Corresponding author: Roberta Fernanda Rogonni Ferrari

Rua Vereador Arecídio Cassiano, 2119 Parque do Lago. CEP: 87.504-645. Umuarama, PR, Brazil. E-mail: betaferrari16@hotmail
} 


\section{Introduction}

Aging is a global phenomenon and may present, among its consequences, the gradual decrease in functional capacity, which is progressive and increases with age and, if not identified early, may cause several pathological conditions. Brazil reaches the highest levels of elderly population. However, these rates reveal that living longer does not always means living better, since aging might bring conditions that make this population need to seek the health services available $^{(1)}$.

The demographic transition in Brazil and the current epidemiological profile with high rates of chronic non-communicable diseases arise the concern for the elderly population, mostly for Systemic Arterial Hypertension, one of the diseases that most affect the individuals $^{(2)}$.

Many of the complications of hypertension result from late diagnosis. Health professionals/nurses have an important role in the diagnosis and control, significantly reducing the complications caused by the disease and other pathological conditions that can affect this population ${ }^{(3)}$. Epidemiological studies on the prevalence of cardiovascular diseases, especially hypertension, are essential to know the distribution, illness and risk factors that may interfere in the community dynamics of risk and control ${ }^{(4)}$.

Hypertension represents a major risk factor for the development of cardiovascular diseases, particularly Stroke and Acute Myocardial Infarction. In Brazil, the number of people with hypertension is increasing. Estimates indicate that there are 17 million people with hypertension, $35 \%$ of the population aged 40 years and older ${ }^{(3)}$.

The Ministry of Health, concerned about this increasingly alarming issue, implemented a population-based survey in 2006 called Vigitel (Surveillance of Risk and Protective Factors for Chronic Diseases by Telephone Survey), in order to verify the distribution of chronic non-communicable diseases in the Brazilian states, revealing that they are responsible for $72 \%$ of total deaths, with diseases of the circulatory system representing $31.3 \%$ of this mortality ${ }^{(5)}$.

Studying the main complaints reported by the elderly in the spaces of care becomes essential to construct the assistance based on the real needs of this age group seeking to develop their autonomy, prevent premature death and disability due to preventable complications ${ }^{(2)}$. For this reason, healthcare practices must be grounded on the living and health conditions, and their inherent singularities. Therefore, it reveals the relevance of knowing the motives that led the elderly with hypertension to health services, since comprehensive care, expanded clinic and personcentered care practices, rather than disease-centered, are guidelines involved in the promotion of health and quality of life, which should permeate initiatives to stimulate autonomy ${ }^{(2)}$.

In this context, the following guiding question was used: What are the reasons that motivated elderly hypertensive patients to seek assistance in primary health care? Thus, this study aimed to investigate the complaints that led elderly with hypertension to seek a health center in a municipality of the State of Paraná, Brazil.

\section{Method}

This is an analytical exploratory study of retrospective type with quantitative approach developed through the analysis of information registered in the medical records of elderly hypertensive patients treated at a primary care unit in a city in northwestern Paraná, Brazil.

It consists of a medium-sized municipality with an elderly population of 12,571 seniors, representing $12.48 \%$ of its inhabitants. Agriculture and the provision of services are the main economic activities. 
It is a reference to other smaller municipalities, having three general hospitals and 23 health units ${ }^{(6)}$.

This health unit has a differentiated care with prior nursing assistance, according to the protocol using the systematization of nursing care, being later forwarded to other professionals.

For the study, 106 medical records of elderly hypertensive patients were randomly selected among the 145 registered and accompanied in this health center. The sample size calculation for setting the number of records to be included in the study was performed in Biostat 5.0 software, considering the total of accompanied elderly ( $\mathrm{N}=145)$, a population proportion of $50 \%$ and a maximum error of estimation of $5 \%$. It is worth highlighting that the number of nursing appointments in the period 20092013 was assessed in the selected records, but only those records concerning the last consultation were considered for analysis, so as to ensure collecting the most recent complaints of hypertensive patients.

Following the parameters established by the Brazilian Statute of the Elderly ${ }^{(7)}$ and the National Policy for the Health of Senior Citizens ${ }^{(8)}$, individuals aged 60 years and older were considered elderly. The inclusion criteria were: aged 60 years and older, residing in a neighborhood covered by the health center in study, and have attended at least one nursing consultation in the last five years (2009-2013) registered in the medical records.

For data collection, a form designed by the researchers themselves divided into three sessions was applied: I. Data regarding socio-demographic characteristics of the elderly (gender, age, education, income, and living with a partner); II. Data concerning the reasons for the elderly to seek the health unit in the last nursing consultation (main complaint and comorbidities); III. Information of nursing assistance (number of nursing consultations in the medical record and nursing interventions prescribed in the last nursing visit).
Data collection occurred from November 2013 to January 2014, which were subsequently recorded and tabulated in spreadsheet of Microsoft Office Excel 2010. For the characterization of the elderly, descriptive statistics was applied, through absolute and relative frequencies. For quantitative variables, descriptive measures of central tendency and variability were presented, which are, respectively, mean and standard deviation (SD), and minimum and maximum values observed. The association between the independent variables and the main complaint was verified by the Chi-square test, using the software Statistica 8.0. In order to measure the association between the variable "Complaint of Hypertension" and the independent variables, the odds ratio (OR) were calculated with respective confidence intervals (CI) of $95 \%$.

The Human Research Ethics Committee of the Universidade Paranaense approved the study under protocol No. 459.53/2013, which was also authorized by the competent agency by signing the Declaration of Permission of Data Use. The Free and Informed Consent Form was not filled out, since only data from medical records were used. Therefore, all ethical principles were respected as required by resolution 466/12.

\section{Results}

The results reveal that of the 106 medical records analyzed, $73.58 \%$ are elderly women, constituting a higher demand of women for the health unit. Elderly people who sought assistance and attended nursing consultations during the study were aged 60-92 years (mean $69.64 \pm 7.48$ years), with greater frequency among those aged $60-70$ years. The majority (83.00\%) had monthly incomes up to four minimum wages (mean $3.09 \pm 1.59$ ) and a maximum of four years of study (73.58\%), while over half of them $(57.55 \%)$ had a partner (Table 1 ). 
Table 1 - Socio-demographic characteristics of elderly hypertensive patients who sought care in a Primary Health Care Center in a municipality in the State of Paraná

\begin{tabular}{ll}
\hline Variables & n (\%) \\
\hline Gender & $28(26.4)$ \\
$\quad$ Male & $78(73.5)$ \\
$\quad$ Female & \\
Age group (years) & $65(61.3)$ \\
$60 \mid---$ - 70 & $25(23.5)$ \\
$70 \mid---80$ & $16(15.1)$ \\
$80 \mid---+$ & \\
Income (minimum wages)* & $42(39.6)$ \\
1 - 2 & $46(43.4)$ \\
3 - 4 & $18(16.9)$ \\
$\geq 5$ & \\
Education (years) & $78(73.5)$ \\
$\leq 4$ & $28(26.4)$ \\
$>4$ & \\
Marital status & $61(57.5)$ \\
With companion & $45(42.5)$ \\
Without companion & \\
\hline Minimum wage of US $\$ 290.12$ &
\end{tabular}

The complaints registered in the records of elderly hypertensive patients, in the last nursing visit, were coded according to the $10^{\text {th }}$ Revision of the International Classification of Diseases - ICD 10. Most reasons for seniors to seek healthcare belonged to conditions included in Chapter IV - Endocrine, nutritional and metabolic diseases (36\%) represented by complaints related to overweight, elevated blood glucose levels and hypercholesterolemia, followed by conditions included in Chapter IX - Diseases of the circulatory system (19\%), characterized by changes in the blood pressure level, headache and lower limb swelling.

Other complaints registered in the records during nursing appointments were associated with conditions relating to Chapter XIII - Diseases of the musculoskeletal system and connective tissue (14\%), XIV - Diseases of the genitourinary system (10\%),
V - Mental and behavioral disorders (8\%), and XII Diseases of the skin and subcutaneous tissue (4\%). It is noteworthy that $9.0 \%$ of the records contain no register of any complaint during nursing visits.

In Table 2, it can be observed that among the 78 women who sought the service and attended the nursing consultation, 33 (42.3\%) reported complaints related to other pathologies than arterial hypertension, such as osteoarthritis, decompensated blood glucose, xerostomia, obesity, dyslipidemia, anxiety, dyspareunia, leukorrhea and dermatitis; additionally, $41 \%$ reported complaints about symptoms of hypertension, such as headache and altered blood pressure levels. It is worth highlighting that both male and female elderly had more complaints related to diseases other than hypertension, with significant association observed between gender and main complaint ( $\mathrm{p}=0.0373$ ).

Likewise, there was a higher frequency of complaints related to other pathologies registered in records of the elderly of all age groups. It is worth mentioning that a lower frequency of complaints was observed among elderly with income greater than five minimum wages and, even in these cases, the complaints were also associated with other group of pathologies than arterial hypertension.

As for education, it was verified that the elderly with up to four years of study presented significantly more complaints $(73.5 \%)$, and these were also in the group of other diseases. Finally, elderly people with partners presented more complaints associated with the group of other diseases (57.5\%), despite no statistically significant difference in the association between these two variables.

Regarding the number of nursing visits registered in the medical records, it was observed an average of 2.31 visits $(S D=1.46)$, ranging from one to seven. Regardless the number of consultations to elderly hypertensive patients in this unit, the prevalence of complaints was related to signs and 
symptoms of other associated diseases rather than hypertension. Among hypertensive elderly who attended more than four nursing visits, a low percentage (10.53\%) of lack of complaints was observed, revealing that the greater the number of consultations, the greater the likelihood of reporting complaints.

It is important mentioning that it was observed a decrease in the number of consultations over the period analyzed, in which almost $80 \%$ of nursing appointments in 2009-2013 were concentrated in 2009.
As regards the nursing interventions performed, it was identified that these were mostly aimed to meet the complaints belonging to the group of other diseases, as well as the consultations. In half the cases, there was only one or two interventions registered corresponding to the records in which the elderly attended nursing appointments without complaints. In cases where there was a record of three or more interventions, it was observed that the nursing care aimed at meeting the needs arising from complaints related to other pathologies, identifying also a significant association between main complaint and number of nursing interventions $\left(\mathrm{p}=0.0007^{*}\right)$.

Table 2 - Socio-demographic and nursing care characteristics associated with complaints by groups of symptoms in elderly hypertensive patients attended in primary care service in a municipality of the State of Paraná

\begin{tabular}{|c|c|c|c|c|c|}
\hline \multirow{3}{*}{ Variable } & \multicolumn{5}{|c|}{ Complaints by groups of symptoms } \\
\hline & $\begin{array}{c}\text { Arterial } \\
\text { hypertension }\end{array}$ & Other diseases & $\begin{array}{c}\text { Without } \\
\text { complaints }\end{array}$ & Total & p value \\
\hline & $\mathrm{n}(\%)$ & n (\%) & $n(\%)$ & n(\%) & \\
\hline \multicolumn{6}{|l|}{ Gender } \\
\hline Male & $4(14.3)$ & $17(60.7)$ & $7(25.0)$ & $28(100.0)$ & \multirow{2}{*}{$0.0373^{*}$} \\
\hline Female & $32(41.0)$ & $33(42.3)$ & $13(16.7)$ & $78(100.0)$ & \\
\hline \multicolumn{6}{|l|}{ Age group (years) } \\
\hline $60 \mid---69$ & $24(36.9)$ & $30(46.1)$ & $11(16.9)$ & $65(100.0)$ & \multirow{3}{*}{0.9115} \\
\hline $70 \mid---79$ & $7(28.0)$ & $12(48.0)$ & $6(24.0)$ & $25(100.0)$ & \\
\hline $80 \mid---+$ & $5(31.2)$ & $8(50.0)$ & $3(18.7)$ & $16(100.0)$ & \\
\hline \multicolumn{6}{|c|}{ Income (minimum wages) } \\
\hline $1-2$ & $16(38.1)$ & $16(38.1)$ & $10(23.8)$ & $42(100.0)$ & \multirow{3}{*}{0.1044} \\
\hline $3-4$ & $13(28.2)$ & $26(56.5)$ & $7(15.2)$ & $46(100.0)$ & \\
\hline$\geq 5$ & $7(38.9)$ & $8(44.4)$ & $3(16.7)$ & $18(100.0)$ & \\
\hline \multicolumn{6}{|l|}{ Education (years) } \\
\hline$\leq 4$ & 31 (39.7) & $33(42.3)$ & $14(17.9)$ & $78(100.0)$ & \multirow{2}{*}{0.5075} \\
\hline$>4$ & $5(17.8)$ & $17(60.7)$ & $6(21.4)$ & $28(100.0)$ & \\
\hline \multicolumn{6}{|l|}{ Marital status } \\
\hline With companion & $16(26.2)$ & $30(49.1)$ & $15(24.6)$ & $61(100.0)$ & \multirow{2}{*}{0.0763} \\
\hline Without companion & $20(44.4)$ & $20(44.4)$ & $5(11.1)$ & $45(100.0)$ & \\
\hline \multicolumn{6}{|l|}{$\mathrm{N}^{\circ}$ of consultations } \\
\hline 1 & $14(36.8)$ & $17(44.7)$ & $7(18.4)$ & $38(100.0)$ & \multirow{4}{*}{0.5798} \\
\hline 2 & $7(21.8)$ & $16(50.0)$ & $9(28.1)$ & $32(100.0)$ & \\
\hline 3 & $7(43.8)$ & $7(43.7)$ & $7(12.5)$ & $16(100.0)$ & \\
\hline$\geq 4$ & $7(36.8)$ & $10(52.6)$ & $2(10.5)$ & $19(100.0)$ & \\
\hline \multicolumn{6}{|l|}{$\mathrm{N}^{\circ}$ de intervenções } \\
\hline $1-2$ & $5(25.0)$ & $5(25.0)$ & $10(50.0)$ & $20(100.0)$ & \multirow{3}{*}{$0.0007 *$} \\
\hline $3-4$ & $16(37.2)$ & $19(44.2)$ & $8(18.6)$ & $43(100.0)$ & \\
\hline$\geq 5$ & $14(33.3)$ & $26(61.9)$ & $2(4.7)$ & $42(100.0)$ & \\
\hline
\end{tabular}


Multivariate analysis shows that there is significant association between gender and complaint related to hypertension as a reason for seeking health services, and that women are from 1.3 to 13.2 more likely to present this type of complaint than men ( $p=0.0109$ ) (Table 3). Nevertheless, no association between complaint related to hypertension and number of interventions prescribed by nurses was observed $(\mathrm{p}=1.00)$.

Table 3 - Risk between the "Complaint of Hypertension" in elderly hypertensive patients and the variables gender and number of nursing interventions in a municipality of the State of Paraná

\begin{tabular}{|c|c|c|c|c|c|c|c|}
\hline \multirow{2}{*}{$\begin{array}{l}\text { Characte- } \\
\text { ristics }\end{array}$} & \multicolumn{3}{|c|}{ Complaint of hypertension } & \multirow{2}{*}{$\begin{array}{c}\mathbf{p} \\
\text { value }\end{array}$} & \multirow{2}{*}{$\begin{array}{l}\text { Odds } \\
\text { ratio }\end{array}$} & \multicolumn{2}{|c|}{ CI } \\
\hline & $\begin{array}{l}\text { With } \\
\text { n (\%) }\end{array}$ & $\begin{array}{c}\text { Without } \\
\text { n (\%) }\end{array}$ & $\begin{array}{l}\text { Total } \\
\text { n (\%) }\end{array}$ & & & $\mathbf{L}_{\mathbf{i}}$ & $\mathbf{L}_{\mathrm{s}}$ \\
\hline \multicolumn{8}{|l|}{ Gender } \\
\hline Male & $\begin{array}{c}4 \\
(14.3)\end{array}$ & $\begin{array}{c}24 \\
(85.7)\end{array}$ & $\begin{array}{c}28 \\
(100.0)\end{array}$ & \multirow{2}{*}{0.011} & \multirow{2}{*}{4.2} & \multirow{2}{*}{1.3} & \multirow{2}{*}{13.2} \\
\hline Female & $\begin{array}{c}32 \\
(41.0)\end{array}$ & $\begin{array}{c}46 \\
(58.9)\end{array}$ & $\begin{array}{c}78 \\
(100.0)\end{array}$ & & & & \\
\hline \multicolumn{8}{|c|}{$\mathrm{N}^{\circ}$ of interventions } \\
\hline $1-4$ & $\begin{array}{c}21 \\
(33.3)\end{array}$ & $\begin{array}{c}42 \\
(66.7)\end{array}$ & $\begin{array}{c}63 \\
(100.0)\end{array}$ & \multirow{2}{*}{1.00} & \multirow{2}{*}{1.0} & \multirow{2}{*}{0.4} & \multirow{2}{*}{2.29} \\
\hline$\geq 5$ & $\begin{array}{c}14 \\
(33.3)\end{array}$ & $\begin{array}{c}28 \\
(66.7)\end{array}$ & $\begin{array}{c}42 \\
(100.0)\end{array}$ & & & & \\
\hline
\end{tabular}

\section{Discussion}

The feminization of old age is already a reality in Brazil. In the last census, conducted in 2010 by the Brazilian Institute of Geography and Statistics, elderly males accounted for 8,549,259 and elderly females for $10,732,790$. This data relates to the longer life expectancy of women, 77.01 years, while that of men is 69.4 years $^{(9)}$. Nonetheless, there are no studies that prove the existence of difference in prevalence between genders ${ }^{(10)}$.

The prevalence of women among elderly with hypertension aged over 60 years was also featured in other research seeking to identify the determinants of active aging and the prevalence of self-reported diabetes among elderly ${ }^{(11-12)}$. Survey conducted with elderly hypertensive patients in a primary health care unit in João Pessoa, Paraíba, Brazil, confirms this finding, which may relate to the fact that women seek health services more often, demonstrating concern for their health and greater knowledge about hypertension, thus being able to control symptoms and disorders when compared to men ${ }^{(13)}$.

It can be observed that women, besides living longer than men, use the health care system more frequently and need more care because of the problems associated with biological, social and economic factors ${ }^{(9,14)}$.

Females with low educational level, advanced age, and low income present higher frailty and tend to seek health care more often ${ }^{(15)}$. Such conditions are present in the setting of most of the population of elderly hypertensive patients studied in this health center, turning the attention to the increased possibility of developing pathological conditions.

As for the years of study, most of the elderly are concentrated in the range of up to four years of education. Corroborating this finding, a study that aimed to describe the socio-demographic and health characteristics among elderly hypertensive patients in the urban area of Uberaba, Minas Gerais, Brazil, identified $55.3 \%$ of the elderly with $1-4$ years of study ${ }^{(16)}$.

Given the confirmed low education of these elderly, it is necessary to make clear and objective nursing guidelines, with language accessible to the level of understanding of each elderly, since understanding directly affects the treatment success.

Most hypertensive elderly in study had a companion, such aspect has been valued in the literature, as it enables the involvement of the partner in health care. Living with companion allows strengthening the therapeutic plan proposed to encourage the participation of both in the self-care activities promoting disease control ${ }^{(17)}$.

Unlike the results found in this study regarding the reporting of main complaints, a study conducted 
with elderly, aiming to identify their reasons to seek the basic healthcare unit, revealed that most of the complaints were related to pain symptoms in all parts of the body, followed by requests of the health care $\operatorname{staff}^{(2)}$.

However, data from this study corroborate the results found in other studies, which describe health problems related to cardiovascular and endocrine disorders as the main complaints in adults and elderly people, particularly hypertension, diabetes mellitus and obesity ${ }^{(18-19)}$.

The complaints of the elderly are multifactorial and are highly important in the global health condition of the aged, allowing professionals to understand that chronic non-communicable diseases affect a greater share of this population, with negative effects with multiple symptoms, serious complications and reactions arising from polypharmacy ${ }^{(18)}$. This may elucidate the prevalence of complaints in the group of other diseases and not only focusing on hypertension, even in the analysis by age groups, education, income, and marital status.

Regardless of how healthy the elderly may be at the age of 60 , this individual needs monitoring of health status when there are no injuries and, in their presence, needs treatment, monitoring, medications, consultations, equipment or materials for therapies, tests in general, among others, besides, of course, social support, so they can live with dignity ${ }^{(20)}$.

Complaints of elderly with hypertension were mostly unrelated to the signs, symptoms and complications of uncontrolled hypertension, rather related to other pathologies, demonstrating knowledge of these seniors about ways to control it and the comprehensive care offered by this service. Therefore, it indicates a paradigm shift in the care of these elderly, to a more enlarged and humanized care, based on the different needs of the elderly and not only on aspects related to hypertension, as usually occurs in the biomedical and technical model ${ }^{(21)}$.

Aging presents specificities marked by the class position of individuals and social groups, as well as by the culture, politics, socioeconomic and health conditions of communities. Health services are essential in meeting the specific needs of the elderly ${ }^{(22)}$.

Many seniors seek this health facility even without complaints, showing that at least part of them seek the health unit looking for preventive care and actions that promote self-care. Visiting the health unit without health complaints means the person is acting proactively to prevent injuries, decreasing their vulnerability and the likelihood of becoming a frail elderly, in addition to preserve the autonomy and increase the likelihood of success in obtaining considerably active aging. Brazilian public health policies have focused on strategies to fight chronic non-communicable diseases, including hypertension, through intersectoral preventive actions and health promotion $^{(23)}$, in which the primary health care centers act with the main strategy in the self-care empowerment of elderly.

This smaller share of elderly seeking the service without complaints demonstrates that, in this service, actions and nursing interventions are not only focused on the biomedical model, also addressing health promotion and disease prevention.

Nevertheless, it is essential to consider the large number of consultations concentrated in 2009, which indicates a major change in the organization and conduct of the service because apparently it stopped prioritizing nursing visits to hypertensive patients. This may have happened because until 2009 this unit served as reference for the treatment of hypertension. It is known that with the decentralization policy of the Unified Health System each basic health unit is in charge of developing activities for hypertensive patients within the coverage area.

Other factors that motivate the search of the elderly, even without reporting complaints, are the characteristics of this health center that has attracted more and more women, due to the multidisciplinary approach of the professionals working in this health unit, because beyond the follow-up of hypertension, 
women are inserted into other programs such as the nursing consultation with the collection of cervical secretions for the early detection of cervical cancer.

For the group of seniors who had complaints during nursing consultations, a large portion was not motivated by complaints related to hypertension but other pathological conditions. Nonetheless, the factors associated with hypertension were also reasons of a representative portion of the search for the health service, always requiring interventions for this disease. It is observed that the elderly of this health center seek the services precisely because of several chronic conditions common to the aging process, an information confirmed by another study conducted $^{(24) \text {. }}$

Given the large amount of needs that must be met, nurses are constantly striving to improve treatment, seeking their own knowledge to systematize the care practice, in which nursing consultation is a strategy that has shown great health benefits for the elderly. Nursing interventions for hypertensive elderly encompass complexities, understanding that the assistance for elderly hypertensive patients should include comprehensive care with home care, multidisciplinary and interdisciplinary activity, guidelines for the elderly, their families and/or caregivers on the proper use of medicines, adoption of healthy lifestyle habits, and diet control ${ }^{(25)}$.

By understanding the reasons that motivate elderly with hypertension to seek health care, nurses can better target assistance and plan educational activities that better meet the interests of those who seek the service. Thus, they are able to promote the effective monitoring of the elderly aiming at maintaining the autonomy and health promotion, behavioral change of risk factors, minimization of health problems that can generate sequels and dependence, thus reaching greater involvement of this group in the self-care process.

Among the limitations of this study, it can be highlighted the difficulty in interpreting some records due to unreadable data and difficulty of access and analysis of medical records given the large flow of care at this health center.

\section{Conclusion}

The results showed that hypertensive elderly (mostly female, aged up to 70 years, with low education, earning up to 4 minimum wages, and living with partner) seek the primary health care unit motivated by complaints that relate to endocrine, cardiovascular and musculoskeletal problems and, in smaller proportion, complaints involving behavioral changes and the genitourinary system.

It was verified the predominance in complaints related to signs and symptoms of other diseases and a smaller portion addressed to hypertension. This pathology, as well as its aggravations, has motivated a lot of research because it is a problem of public health relevance. Nonetheless, the care of the elderly cannot be reduced to a single pathology but in the multitude of modifications and adaptations that this stage of life imposes on them.

These results are utterly important for the development of specific interventions to elderly hypertensive patients seeking primary health care with assistance to their real biopsychosocial needs in supporting the actions of health promotion in self-care, since that care demands are diverse and go beyond the biological dimension. This research will enable nurses to adapt and change their daily practice, contemplating a care based on multidimensional assessment in order to detect health problems that require intervention, given the multiplicity of needs that must be met and thus address the care to the comprehensive well-being and improve the quality of life for seniors.

Further studies should be conducted with the elderly in different contexts, verifying the association of complaints with socio-demographic characteristics, health behavior and nursing care, enabling early intervention and enhancing nursing interventions, as the elderly population becomes increasingly present in health services. 


\section{Collaborations}

Ferrari RFR, Ribeiro DMM and Vidigal FC contributed to the design, field data collection, analysis, interpretation of data, and drafting of the article. Marcon SS, Baldissera VDA and Carreira L contributed to the design and final approval of the version to be published.

\section{References}

1. Ferreira OGL, Maciel SC, Costa SMG, Silva AO, Moreira MASP. Envelhecimento ativo e sua relação com a independência funcional. Texto Contexto Enferm. 2012; 21(3):513-8.

2. Rosa MRQP, Patrício ZM, Silvério MR, Rumel D. Reasons that made aged people seek care at a basic health unit. Rev Latino-Am Enfermagem. 2009; 17(5):670-6.

3. Organização Pan-Americana da Saúde. Linhas de cuidado: hipertensão arterial e diabetes. [Internet] 2010 [citado 2014 abr 23]. Disponível em: http://apsredes.org/site2012/wpcontent/ uploads/2012/05/linhas_cuidado_hipertensao_ diabetes.pdf

4. Cavalheiro AS, Fonseca MJ, Sbruzzi G, Goldmeier S. Perfil de pacientes atendidos em um ambulatório de hipertensão arterial: há diferenças entre sexos? Rev Gaúcha Enferm. 2014; 35(1):110-5.

5. Ministério da Saúde (BR). Secretaria de Vigilância em Saúde. Vigitel Brasil 2011: vigilância de fatores de risco e proteção para doenças crônicas por inquérito telefônico. Brasília: Ministério da Saúde; 2012.

6. Instituto Paranaense de Desenvolvimento Econômico e Social (IPARDES). Cad Estat Munic. [periódico na Internet] 2013 [citado 2014 mar 20]; 1-32. Disponível em: http://www.ipardes.gov. br/cadernos/Montapdf.php?Municipio=87500

7. Brasil. Lei no 10741, de 1ํ de outubro de 2003. Estatuto do idoso [Internet] 2003 [citado 2014 mar 20]. Disponível em: URL: http://www. planalto.gov.br/ecivl_03/leis/2003/L10.741

8. Brasil. Portaria $\mathrm{n}$ o 2.528 de 19 de outubro de 2006. Aprova a Política Nacional de Saúde da
Pessoa Idosa [Internet] 2006 [citado 2014 mar 20]. Disponível em: http://www.planalto.gov.br

9. Caldeira S, Merighini MAB, Muñoz LA, Jesus MCP, Domingos SRF, Oliveira DM. Nurses and care delivery to elderly women: a social phenomenological approach. Rev Latino-Am Enfermagem. 2012; 20(5):888-5.

10. Sociedade Brasileira de Cardiologia, Sociedade Brasileira de Hipertensão. Sociedade Brasileira de Nefrologia. VI Diretrizes brasileiras de hipertensão. Arq Bras Cardiol. 2010; 95(1):1-51.

11. Farias RG, Santos SMA. Influência dos determinantes do envelhecimento ativo entre idosos mais idosos. Texto Contexto Enferm. 2012; 21(1):167-76.

12. Francisco PMSB, Belon AP, Barros MBA, Carandina L, Alves MCGP, Goldabaum M, et al. Diabetes autoreferido em idosos: prevalência, fatores associados e práticas de controle. Cad Saúde Pública. 2010; 26(1):175-84.

13. Dourado CS, Macêdo-Costa KNF, Oliveira JS, Leadeball ODCP, Silva GRF. Adesão ao tratamento de idosos com hipertensão em uma unidade básica de saúde de João Pessoa, Estado da Paraíba. Acta Sci Health Sci. 2011; 33(1):9-17.

14. Ribeiro AP, Souza ER, Valadares FC. Atendimento de saúde para pessoas idosas vítimas de violência no município do Rio de Janeiro. Ciênc Saúde Coletiva. 2012; 17(5):1167-77.

15. Santos AA, Mansano-Schlosser TCS, Ceolim MF, Pavarini SCI. Sono, fragilidade e cognição: estudo multicêntrico com idosos brasileiros. Rev Bras Enferm. 2013; 66(3):351-7.

16. Diniz MA, Tavares DMS, Rodrigues LR. Características sócio-demograficas e de saúde entre idosos com hipertensão arterial. Ciênc Cuid Saúde. 2009; 8(4):607-14.

17. Tavares DMS, Martins NPF, Dias FA, Diniz MA. Qualidade de vida de idosos com e sem hipertensão arterial. Rev Eletr Enf. [periódico na Internet] 2011 [citado 2014 mar 20]; 13(2):2118. Disponível em: http://www.fen.ufg.br/fen_ revista/v13/n2/pdf/v13n2a07.pdf

18. Cabrelli R, Sousa CS, Turrini RNT, Cianciarullo TI. The elderly in family health units: morbidity and use of health care services. Rev Rene. 2014; 
15(1):89-98.

19. Malfatti CRM, Assunção, AN. Hipertensão arterial e diabetes na Estratégia de Saúde da Família: uma análise da frequência de acompanhamento pelas equipes de Saúde da Família. Ciênc Saúde Coletiva. 2011; 16(Suppl 1):1383-8.

20. Santos AS, Karsch UM, Menendez Montanes C. A rede de serviços de atenção à saúde do idoso na cidade de Barcelona (Espanha) e na cidade de São Paulo (Brasil). Serv Soc Soc. 2010; 102:365-86.

21. Marin MJ, Santana FHS, Moracvick MYAD. The perception of hypertensive elderly patients regarding their health needs. Rev Esc Enferm USP. 2012; 46(1):103-10.

22. Alvarenga MRM, Oliveira MAC, Domingues MAR, Amendola F, Faccenda O. Rede de suporte social do idoso atendido por equipes de Saúde da Família. Ciênc Saúde Coletiva. 2011; 16(5):260311.

23. Gadenz SD, Benvegnu LA. Hábitos alimentares na prevenção de doenças cardiovasculares e fatores associados em idosos hipertensos. Ciênc Saúde Coletiva. 2013; 18(12):3523-33.

24. Veras RP. Estratégias para o enfrentamento das doenças crônicas: um modelo em que todos ganham. Rev Bras Geriatr Gerontol. 2011; 14(4): 779-86.

25. Pinheiro GML, Alvarez AM, Pires DEP. A configuração do trabalho da enfermeira na atenção ao idoso na Estratégia de Saúde da Família. Ciênc Saúde Coletiva. 2012; 17(8):2105-15. 